\title{
Molecular Pathology in the Lungs of Severe Acute Respiratory Syndrome Patients
}

\author{
Juxiang Ye, ${ }^{*}$ Bo Zhang, ${ }^{*}$ Jian $\mathrm{Xu},{ }^{\dagger}$ Qing Chang, ${ }^{*}$ \\ Michael A. McNutt, ${ }^{*}$ Christine Korteweg, ${ }^{*}$ \\ Encong Gong, ${ }^{*}$ and Jiang Gu* \\ From the Department of Pathology,* School of Basic Medical \\ Science, Peking University Health Science Center, Beijing, China; \\ the Department of Histology and Embryology, ${ }^{\dagger}$ Peking University \\ Health Science Center, Beijing, China; and the Department of \\ Patbology, ${ }^{\ddagger}$ State University of New York-Health Science Center at \\ Brooklyn, Brooklyn, New York
}

Severe acute respiratory syndrome (SARS) is a novel infectious disease with disastrous clinical consequences, in which the lungs are the major target organs. Previous studies have described the general pathology in the lungs of SARS patients and have identified some of the cell types infected by SARS coronavirus (SARS-CoV). However, at the time of this writing, there were no comprehensive reports of the cellular distribution of the virus in lung tissue. In this study, we have performed double labeling combining in situ hybridization with immunohistochemistry and alternating each of these techniques separately in consecutive sections to evaluate the viral distribution on various cell types in the lungs of seven patients affected with SARS. We found that SARS-CoV was present in bronchial epithelium, type I and II pneumocytes, T lymphocytes, and macrophages/monocytes. For pneumocytes, $T$ lymphocytes, and macrophages, the infection rates were calculated. In addition, our present study is the first to demonstrate infection of endothelial cells and fibroblasts in SARS. (Am J Pathol 2007, 170:538-545; DOI: 10.2353/ajpath.2007.060469)

The outbreak of a seemingly new infectious disease, severe acute respiratory syndrome (SARS) with a mortality of $\sim 10 \%$, caused the death of 774 individuals (World Health Organization: http://www.who.int/csr/sars/country/ table2004_04_21/en/index.htm/). The majority of SARS patients showed severe lower respiratory symptoms, chiefly with a dry cough and progressive dyspnea, with respiratory failure as the major cause of death. ${ }^{1}$ Previous reports have demonstrated significant pathological changes in lung tissues of SARS patients, such as diffuse alveolar damage, pulmonary edema, interstitial mononuclear inflammatory infiltrates, and desquamation of pneumocytes into alveolar spaces. ${ }^{2-8}$ The SARS coronavirus (SARS-CoV) has been detected in pneumocytes, , ${ }^{4-13}$ macrophages, ${ }^{10-13}$ and lymphocytes. ${ }^{12}$

Clinical and histopathological data have revealed that the lungs are the main target organs of SARS-CoV, and a more detailed understanding of the pathology in pulmonary tissue will most likely provide insight into the pathogenesis of SARS and the role of SARS-CoV in particular. Up to this point, however, there has been no comprehensive description of the cells targeted by SARS-CoV in lung tissues. In some cases, discrepancies have occurred in reporting the

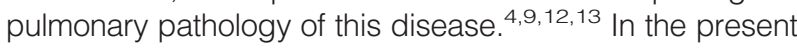
study, in addition to conventional histopathology, we applied a combination of in situ hybridization, immunohistochemistry $(\mathrm{IHC})$, and histochemistry $(\mathrm{HC})$ of pulmonary tissues to evaluate the cellular distribution of the virus in pneumocytes, lymphocytes, macrophages, endothelial cells, and fibroblasts of the lungs.

\section{Materials and Methods}

Seven SARS cases were identified among autopsy specimens from the Department of Pathology, Peking University Health Science Center. All of these cases met the diagnostic criteria for SARS as defined by the World Health Organization. Clinical information for each of these patients is presented in Table 1. Specimens were fixed in 10\% formalin and embedded in paraffin. All lung tissue sections were of $5-\mu \mathrm{m}$ thickness, and consecutive sections were prepared. Hematoxylin and eosin (H\&E) stain was performed on these tissue sections. Lung tissues from three noninfectious pa-

Supported by China National 863 (project no. 2003AA 208107) and the Ministry of Education, China (no.104184).

Accepted for publication October 13, 2006.

Address reprint requests to Jiang Gu, M.D., Ph.D., Professor and Chairman, Department of Pathology, Dean, School of Basic Medical Sciences, Director, Infectious Disease Center, Peking (Beijing) University, 38 Xueyuan Rd., Beijing 100083, China; or Clinical Professor, State University of New York-Health Science Center at Brooklyn, Brooklyn, NY E-mail: jianggu@bjmu.edu.cn. 
Table 1. Clinical Information of Investigated SARS Patients

\begin{tabular}{|c|c|c|c|c|c|c|c|}
\hline $\begin{array}{c}\text { Case } \\
\text { no. }\end{array}$ & Age/sex & $\begin{array}{l}\text { Course } \\
\text { (days) }\end{array}$ & Clinical symptoms & $\begin{array}{l}\text { SARS pathogen } \\
\text { (real-time PCR) }\end{array}$ & Chest radiograph & Lymphopenia & $\begin{array}{l}\text { Steroid } \\
\text { treatment }\end{array}$ \\
\hline 001 & $51 / \mathrm{M}$ & 45 & Fever and cough & Yes & Infiltrates in lower portion of right lung & Yes & + \\
\hline 003 & $50 / \mathrm{M}$ & 33 & $\begin{array}{l}\text { Fever, cough, and } \\
\text { shortness of breath }\end{array}$ & Yes & Bilateral ground glass changes & Yes & - \\
\hline 005 & $31 / \mathrm{M}$ & 35 & $\begin{array}{l}\text { Fever and nonproductive } \\
\text { cough }\end{array}$ & Yes & $\begin{array}{l}\text { Ground glass changes in periphery of } \\
\text { left lower and right middle lobes }\end{array}$ & Yes & + \\
\hline 006 & $49 / F$ & 32 & $\begin{array}{l}\text { Fever and shortness of } \\
\text { breath }\end{array}$ & Yes & Interstitial infiltrates & Yes & + \\
\hline 008 & 24/M & 21 & Fever and cough & Yes & Bilateral patchy exudates in lower lobes & Yes & + \\
\hline 011 & $20 / \mathrm{M}$ & 58 & Fever and cough & Yes & $\begin{array}{l}\text { Bilateral patchy interstitial infiltrates in } \\
\text { lower lobes }\end{array}$ & Yes & + \\
\hline 015 & $58 / \mathrm{M}$ & 62 & $\begin{array}{l}\text { Fever, cough, and chest } \\
\text { distress }\end{array}$ & Yes & $\begin{array}{l}\text { Bilateral patchy ill-defined air-space } \\
\text { shadowing }\end{array}$ & Yes & + \\
\hline
\end{tabular}

M, male; $F$, female.

tients and four SARS-negative patients with pulmonary infectious diseases served as negative controls.

\section{Preparation of CRNA Probes}

Total RNA of SARS-CoV was extracted from serum of SARS patients. The virus genome sequence was obtained from GenBank (accession number AY274119), and a pair of primers were designed to amplify specifically the fragment of the polymerase gene (R1ab) by reverse transcriptase-polymerase chain reaction (RTPCR): 5'-GCGCAAGTATTAAGTGAGATG-3' (15,348 to 15,368 nucleotides) and 5'-GAAGTGCATTTACATTGGCT-3' (15,473 to 15,492 nucleotides). The amplified fragment was then recombined with plasmid vector pGEM-T (Promega Corp., Madison, WI), which contains one Sall and one Ncol fragment site. A 154-nucleotide CRNA probe was generated by in vitro transcription and was labeled with digoxigenin (Roche Diagnostics, Penzberg, Germany).

\section{In Situ Hybridization}

To evaluate the cellular distribution of SARS-CoV in the lungs, in situ hybridization was performed based on the protocol of Zhang and colleagues. ${ }^{14}$ In brief, before hybridization incubation, all solutions were prepared with diethyl pyrocarbonate-treated water. After deparaffinization and rehydration, tissue sections were treated by proteinase $\mathrm{K}$ digestion or microwave heating and were then incubated with hybridization cocktail containing $50 \mu \mathrm{g} / \mathrm{ml}$ SARS probe at $45^{\circ} \mathrm{C}$ for 16 hours. After blocking with normal horse serum (1:100), sections were next incubated with alkaline phosphatase-labeled anti-digoxigenin antibody (1:500) (Roche Diagnostics) for 1 hour, and the reaction products were colorized with nitro blue tetrazolium/5-bromo-4-choloro-3indolyl phosphate (NBT/BCIP) (Promega Corp.), resulting in a purple-blue signal. Some slides were counterstained with methyl green. Signal specificity was assessed by substitution of the probe by an irrelevant probe of similar nucleotide content and length against the nucleoprotein of the H5N1 virus.

\section{Immunohistochemistry}

$\mathrm{IHC}$ was performed as described by Lin and colleagues. ${ }^{15}$ Briefly, paraffin-embedded tissue sections were deparaffinized and immersed in 3\% hydrogen peroxide to eliminate endogenous peroxidase activity. Antigen retrieval was performed by heating the tissue sections at $96^{\circ} \mathrm{C}$ in $0.01 \mathrm{~mol} / \mathrm{L}$ citrate buffer ( $\mathrm{pH}$ 6.0) for 20 minutes. Primary monoclonal antibodies including those to cytokeratin $A E 1 / 3(C K), C D 3$, CD68, and CD34 were used to identify epithelial cells, T lymphocytes, macrophages, and endothelial cells, respectively. Vimentin immunostaining was used to identify fibroblasts. The sources, dilutions, and incubation times of each primary antibody are listed in Table 2. Optimal contrast between the specific labeling and the background for each antigen was achieved using a PV9000 immunohistochemistry kit containing polyperoxidase anti-mouse/rabbit IgG (Zymed Laboratories, South San Francisco, CA). To visualize specific signals, a DAB (3,3'-diamino-benzidine-tetrahy-

Table 2. Antibodies for IHC

\begin{tabular}{|c|c|c|c|c|c|}
\hline $\begin{array}{l}\text { Primary monoclonal } \\
\text { antibody }\end{array}$ & Supplied by & Cell marker for & $\begin{array}{l}\text { Dilution or } \\
\text { concentration }\end{array}$ & $\begin{array}{l}\text { Incubation } \\
\text { temperature }\end{array}$ & $\begin{array}{l}\text { Incubation } \\
\text { period }\end{array}$ \\
\hline CD3 & $\begin{array}{l}\text { Zymed Laboratories, } \\
\text { South San Francisco, CA }\end{array}$ & T cell & $1: 100$ & $4^{\circ} \mathrm{C}$ & Overnight \\
\hline CD68 & Zymed Laboratories & Macrophage, monocyte & $1: 100$ & $4^{\circ} \mathrm{C}$ & Overnight \\
\hline Cytokeratin (AE1/AE3) & Zymed Laboratories & Epithelial cell & $1: 100$ & $4^{\circ} \mathrm{C}$ & Overnight \\
\hline CD34 & Zymed Laboratories & Endothelial cell & $1: 100$ & $4^{\circ} \mathrm{C}$ & Overnight \\
\hline Vimentin & Zymed Laboratories & Fibroblast & $1: 100$ & $4^{\circ} \mathrm{C}$ & Overnight \\
\hline Neurofilament & Zymed Laboratories & Neuron & $1: 100$ & $4^{\circ} \mathrm{C}$ & Overnight \\
\hline Tubulin & Zymed Laboratories & Ciliated cell & $1: 100$ & $4^{\circ} \mathrm{C}$ & Overnight \\
\hline
\end{tabular}


Table 3. Sources of Reagents for Masson Trichrome Stain

\begin{tabular}{ll}
\hline \multicolumn{1}{c}{ Reagent } & \multicolumn{1}{c}{ Supplied by } \\
\hline Trichloroacetic acid & Beijng Xingjin Chemical Co. Ltd., Beijing, China \\
Potassium dichromate & Beijng Huateng Chemical Co. Ltd., Beijing, China \\
Celestin blue & Beijing Chemical Reagents Company, Beijing, China \\
Mayer hematoxylin & Beijng Huateng Chemical Co. Ltd. \\
Ponceau & Beijing Chemical Reagents Company \\
Phosphomolybic acid tetracosahydrate (PAT) & Tianjin Kermal Chemical Reagent Co. Ltd., Tianjin, China \\
Acetic acid & Beijng Huateng Chemical Co. Ltd. \\
Light green & Beijing Chemical Reagents Company \\
\hline
\end{tabular}

drochloride) substrate chromogen kit (Zymed Laboratories) was used. Slides were counterstained with hematoxylin. In negative controls, the primary antibody was omitted or replaced by isotype-matched monoclonal antibodies including those against neurofilament and tubulin.

\section{In Situ Hybridization and IHC Double Labeling}

Double labeling combining in situ hybridization and $\mathrm{IHC}$ was used to identify the cell type of in situ hybridization-positive cells. After the in situ hybridization colorization reaction, sections were incubated with $3 \%$ hydrogen peroxide to quench endogenous peroxidase activity and then reacted with monoclonal antibodies to cytokeratin AE1/3 (CK), vimentin, CD3, CD34, or CD68 with incubation overnight at $4^{\circ} \mathrm{C}$. After washing in phosphate-buffered saline, sections were incubated with goat anti-mouse IgG labeled with horseradish peroxidase at room temperature for $30 \mathrm{~min}$ utes. Antibodies binding to cells of interest were detected with the horseradish peroxidase reaction kit AEC, which gives a red reaction color. For every case, double labeling with $\mathrm{IHC}$ and in situ hybridization was repeated three times for data analysis. To strengthen further the results of colocalization, we performed in situ hybridization and $\mathrm{IHC}$ on consecutive sections. Tissue sections showing in situ hybridization-positive cells were carefully compared with consecutive tissue sections on which IHC with antibodies against specific cell markers was applied. Co-localization of a specific cellular marker and viral genome was clearly identified.

\section{Masson Trichrome Stain}

In addition to vimentin immunostaining, Masson trichrome stain was used on consecutive tissue sections as a further means to identify fibroblasts. The sources for each component of the Masson trichrome stain are listed in Table 3. Paraffin-embedded tissue sections were deparaffinized and treated sequentially with solutions of $10 \%$ trichloroacetic acid and $10 \%$ potassium dichromate
(1:1), $1 \%$ celestine blue, Mayer hematoxylin, and $1 \%$ fuchsin acid and 1\% Ponceau S (2:1). Next, sections were rinsed in $1 \%$ phosphomolybdic acid tetracosahydrate and $0.5 \%$ acetic acid. Finally, $1 \%$ light green was added, and the sections were rinsed again in phosphomolybdic acid tetracosahydrate and acetic acid.

\section{Data Analysis}

Five fields per section in which IHC-positive cells were relatively abundant were selected randomly using a $\times 20$ light microscope objective (Nikon Eclipse E800; Yokohama, Japan). These selected fields showed mainly bronchi or bronchioles and alveoli. Cells positive for one specific IHC marker were counted, and cells showing both positive in situ hybridization and $\mathrm{IHC}$ signals (positive double labeling) were also counted. The identity of the cells showing co-localization was confirmed by performing in situ hybridization and $\mathrm{IHC}$ separately on consecutive sections as described above. The infection rates of each of the three cell types as identified by $\mathrm{IHC}$ were derived from cell counts (cells showing positive double labeling/total number of cells positive for a specific $\mathrm{IHC}$ marker). All evaluations were performed in a doubleblinded manner. The infection rate of each of the three cell types was graded according to the following criteria: 1) cell infection rates less than $10 \%$ were regarded as grade I and were marked with $+; 2$ ) cell infection rates between $10 \%$ and $20 \%$ were regarded as grade $\mathrm{II}$ and were marked with ++ ; and 3 ) cell infection rates exceeding $20 \%$ were regarded as grade III and were marked with +++ . The infection rates for each specific cell type and the semiquantifications of the infection rates are presented in Tables 4 and 5. Infection rates of endothelial cells and fibroblasts were not calculated because the absolute numbers of infected endothelial cells were very small and because of the lack of a specific marker for fibroblasts in general.

Table 4. Infection Rates of Different Cell Types

\begin{tabular}{lrrrrrrrr}
\hline & Case 001 & Case 003 & Case 005 & Case 006 & Case 008 & Case 011 & Case 015 & Mean \\
\hline CD3 $(+)$ cells & $4.3 \%$ & $14.9 \%$ & $15 \%$ & $6.4 \%$ & $36.7 \%$ & $4.0 \%$ & $13.7 \%$ & $13.6 \%$ \\
CK $(+)$ cells & $27.1 \%$ & $5.9 \%$ & $7.0 \%$ & $11.5 \%$ & $69.8 \%$ & $38.9 \%$ & $4.6 \%$ & $23.5 \%$ \\
CD68 $(+)$ cells & $7.6 \%$ & $5.2 \%$ & $4.8 \%$ & $5.3 \%$ & $5.3 \%$ & $4.6 \%$ & $3.2 \%$ & $6.3 \%$ \\
\hline
\end{tabular}


Table 5. Semiquantification of the Infection Rates for Each Cell Type

\begin{tabular}{|c|c|c|c|c|c|c|c|c|}
\hline & Grade & Case 001 & Case 003 & Case 005 & Case 006 & Case 008 & Case 011 & Case 015 \\
\hline \multirow{3}{*}{ CD3 $(+)$} & I & + & & & + & & + & \\
\hline & II & & ++ & ++ & & & & ++ \\
\hline & III & & & & & +++ & & \\
\hline \multirow[t]{2}{*}{$\mathrm{CK}(+)$} & I & & + & + & & & & + \\
\hline & II & +++ & & & ++ & $+t+$ & $+t+$ & \\
\hline \multirow{2}{*}{ C68 (+) } & I & + & + & + & + & & $\begin{array}{c}+++ \\
+\end{array}$ & + \\
\hline & $\begin{array}{l}\text { II } \\
\text { III }\end{array}$ & & & & & ++ & & \\
\hline
\end{tabular}

\section{Statistical Analysis}

Scatter plots comparing the infection rates of the different cell types as well as comparing disease duration and infection rates were prepared to detect general trends. A Spearman correlation test (version 8.0; SAS, Cary, NC) was performed to further evaluate a potential correlation between the different variables. $P<0.05$ was considered statistically significant.

\section{Results}

\section{Bronchial Epithelium}

Most bronchial epithelium was found intact by light microscopic evaluation, but epithelium was focally de- tached in cases 008 and 011. Both intact and detached epithelium showed strong positive in situ hybridization signals. Double labeling, combining in situ hybridization and IHC with antibodies against CK, confirmed the identity of these cells as epithelial cells (Figure 1, A and E).

\section{Pneumocytes}

There were many round- and spindle-shaped cells scattered or clustered in collapsed alveolar spaces, and the morphological features of these cells were consistent with type II pneumocytes (Figure 1B). Positive IHC with antibodies to CK confirmed that these were epithelial cells (Figure 1C). In situ hybridization on consecutive sections and double labeling showed that some of these
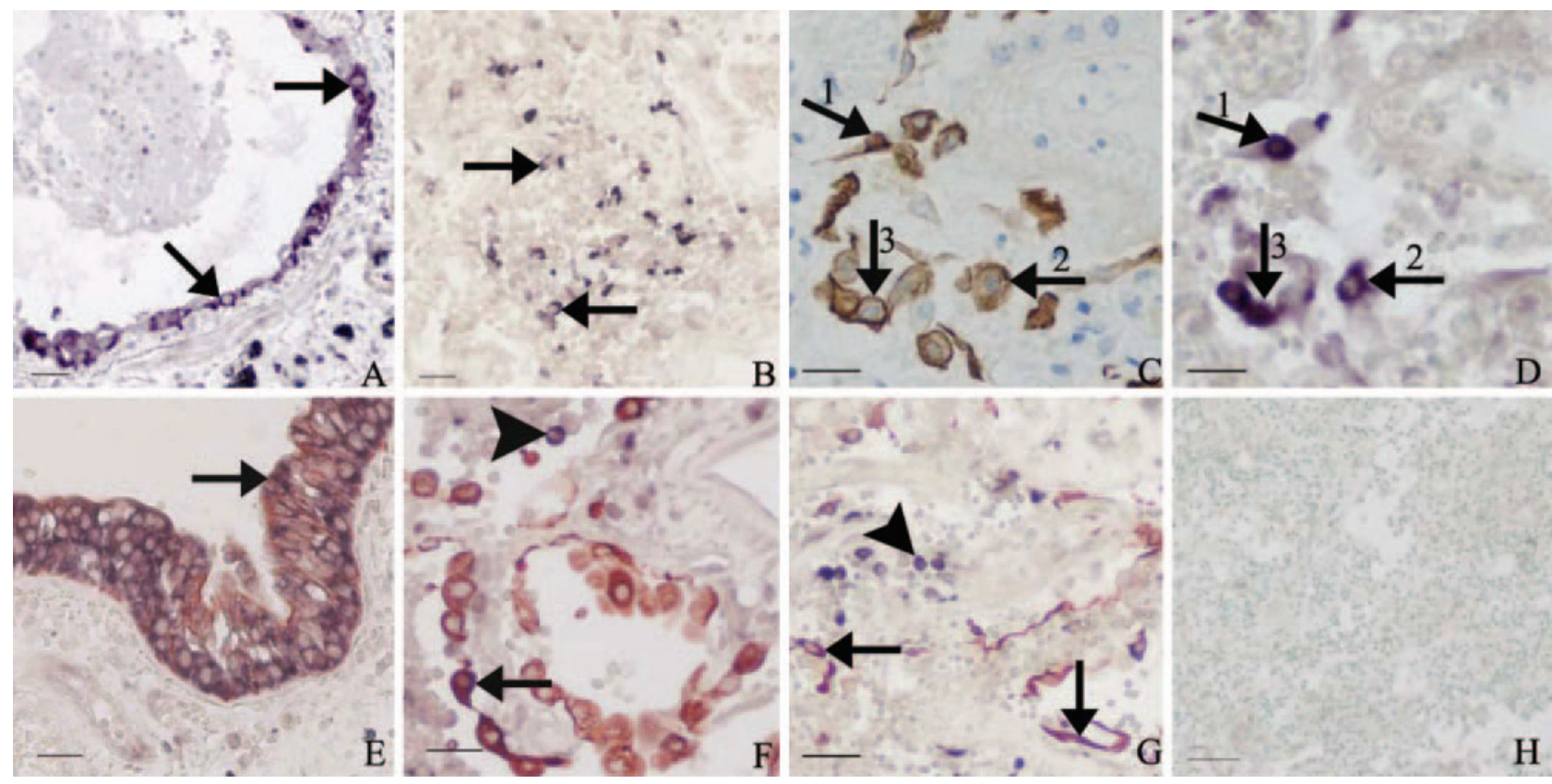

Figure 1. Photos demonstrating SARS-CoV infection of epithelial cells in the lungs of SARS patients. A: Intact bronchial epithelium showing positive viral signals in the cytoplasm of the epithelial cells as detected by in situ hybridization (in situ hybridization signals, purplish blue; arrows). B: In situ hybridization shows positive viral signals in many round- or spindle-shaped cells in a collapsed lung air space ( in situ hybridization signals, dark blue; arrows). C: IHC with antibodies to CK demonstrates pneumocytes partly desquamated into the alveoli with morphological characteristics of type II pneumocytes (IHC signals, brown; arrows). D: SARS-CoV genomic sequences are detected by in situ hybridization in the same CK-positive cells as shown in $\mathbf{C}$ ( in situ hybridization signals, purplish blue arrows, consecutive section to C). E: Double labeling with in situ hybridization and IHC detects co-localization of SARS-CoV and CK in the cytoplasm of bronchial epithelial cells (CK IHC signals, brownish red; in situ hybridization signals, dark blue; arrow). F: Lung tissue showing a large number of CK-positive cells (CK IHC signals, brownish red) with morphological features of type II pneumocytes in the alveoli. Positive in situ hybridization signals are seen in some of these cells (combined IHC and in situ hybridization signals, purplish blue; arrow) and in some round CK-negative cells (in situ hybridization signals, dark blue; arrowhead). G: Double labeling with in situ hybridization and IHC detects SARS-CoV in many CK-positive pneumocytes including type I pneumocytes (arrows) and in some round CK-negative cells (arrowhead). H: Negative control for in situ hybridization with an irrelevant probe showing no positive signals in SARS-CoV-infected lung tissue (counterstained with methyl green). Scale bars: $25 \mu \mathrm{m}(\mathbf{A}, \mathbf{B}, \mathbf{E}, \mathbf{G}, \mathbf{H}) ; 20 \mu \mathrm{m}(\mathbf{C}, \mathbf{D}, \mathbf{F})$. 

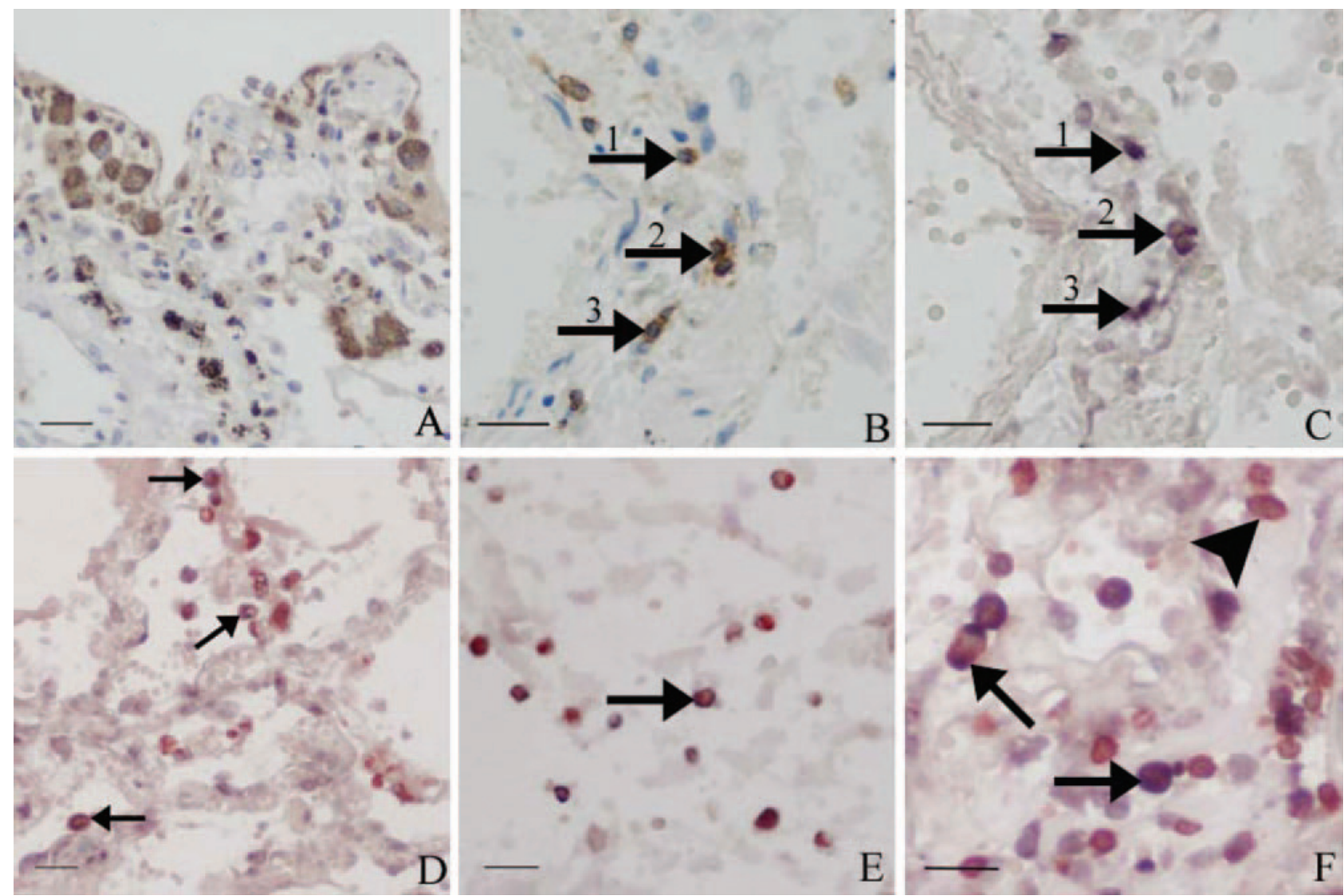

Figure 2. Photos demonstrating SARS-CoV infection of lymphocytes and macrophages in the lungs of SARS patients. A: IHC with antibodies to CD68 demonstrates many large foamy macrophages in the lung interstitium (IHC signals, brown). B: Lung tissue showing many T lymphocytes (CD3-positive) in the interstitium of the lungs (IHC signals, brown; arrows). C: Positive in situ hybridization signals in the cytoplasm of some of the mononuclear cells that show positive CD3 staining in $\mathbf{B}$ (consecutive section to B). D: Double labeling with CD68 and in situ hybridization detects positive in situ hybridization signals in large foamy macrophages (IHC signals, brownish red; in situ hybridization signals, blue; arrows). E: SARS-CoV genomic sequences are detected in some small CD68-positive cells (in situ hybridization signals, blue; IHC signals, brownish red; arrow). F: Positive in situ hybridization signals in T lymphocytes in the alveolar space and interstitium. Both brownish red IHC (CD3) signals and dark blue in situ hybridization signals are present in the same cells (arrows). There are also many uninfected CD3-positive cells (brownish red signals only; arrowhead). Scale bars: $25 \mu \mathrm{m}(\mathbf{A}, \mathbf{D}, \mathbf{E}) ; 20 \mu \mathrm{m}(\mathbf{B}, \mathbf{C}, \mathbf{F})$.

epithelial cells harbored SARS-CoV genomic sequences (Figure 1, C, D, and F). Both positive in situ hybridization and positive $\mathrm{IHC}$ signals were also found localized in the cytoplasm of some alveolar lining cells with morphological characteristics of type I pneumocytes (Figure 1G). The infection rates of CK-positive cells are shown in Tables 4 and 5. The average infection rate for seven cases was $14.6 \%$. The highest infection rates were found in cases 008 and 011 (69.8 and 38.9\%, respectively), representing the youngest two patients in this series of SARS cases (Tables 1 and 4).

\section{Leukocytes}

In the lung tissues of the present SARS cases, significant numbers of inflammatory cells were found in the alveolar spaces and in the interstitium. Strong positive in situ hybridization signals were present in many round CK-negative cells, most likely representing inflammatory cells (Figure 1G). IHC showed that several of such cells were CD68-positive (Figure 2A). In addition, many of these cells were large and foamy or vacuolated, such features being consistent with the general morphology of macro- phages (Figure 2A). Double labeling combining in situ hybridization and $\mathrm{IHC}$ with antibodies against CD68 showed that in a subset of the large CD68-positive cells, viral genomic sequences were present (Figure 2D). In addition, there were also a few small CD68-positive cells in which SARS-CoV was detected (Figure 2E).

Many cells expressing CD3 were also found scattered in the interstitium (Figure 2B). On consecutive sections in situ hybridization demonstrated that SARS-CoV could be detected in the cytoplasm of several CD3-positive cells (Figure 2, B and C). Double labeling confirmed the infection of lymphocytes (Figure 2F). The infection rates of CD3-positive cells are shown in Tables 4 and 5. The average infection rate of CD3-positive cells over the seven cases was $13.6 \%$, whereas a higher percentage $(36.7 \%)$ of infected cells was observed in case 008.

\section{Vascular Endothelial Cells}

Positive in situ hybridization signals were clearly present in the cytoplasm of a few of the endothelial cells (Figure 3B). 

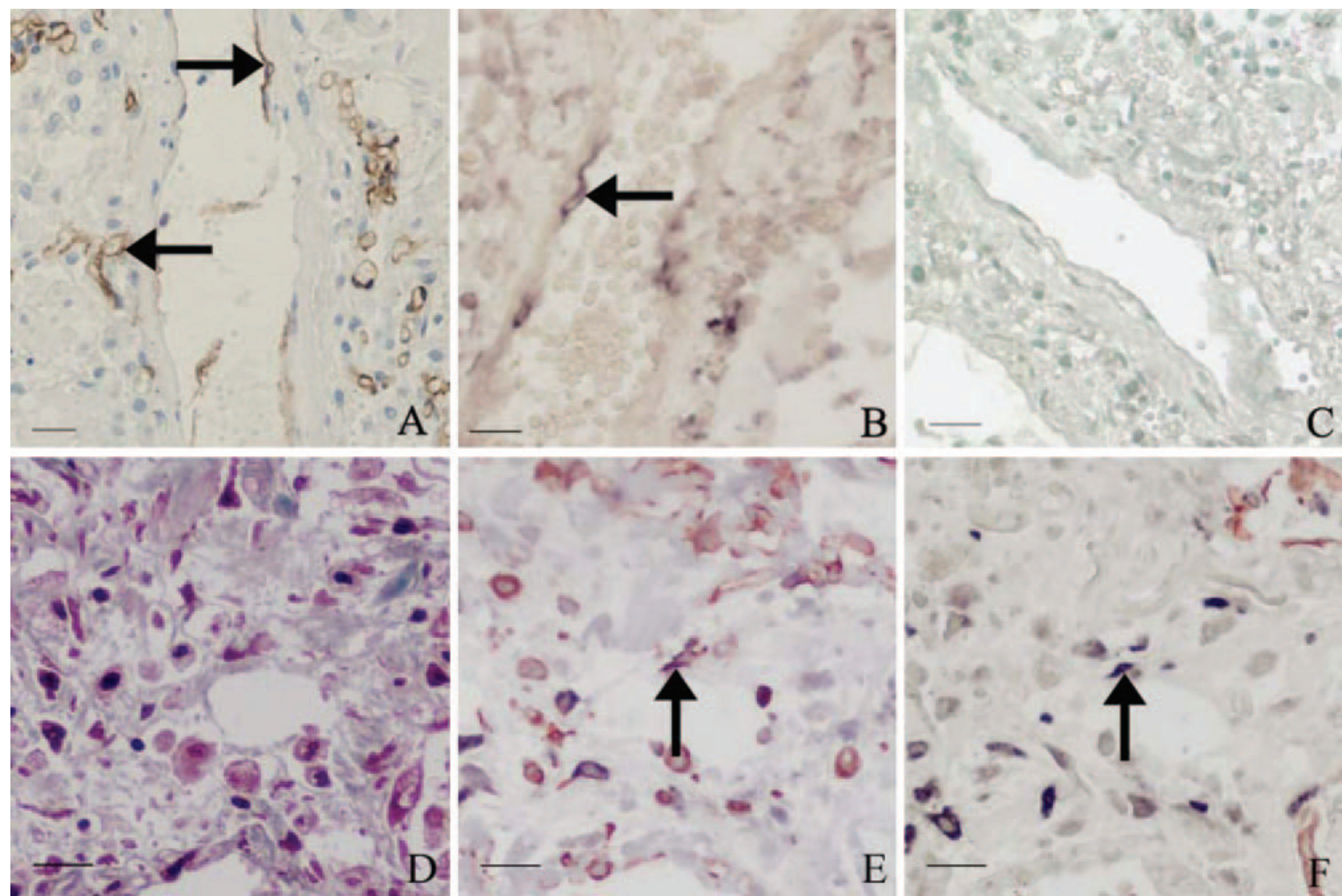

Figure 3. Photos demonstrating the presence of SARS-CoV sequence in endothelial cells and fibroblasts in the lungs of SARS patients. A: IHC with antibodies to CD34 identifies endothelial cells (IHC signals, brown; arrows) in lungs. B: Positive in situ hybridization signals in the cytoplasm of vascular endothelium (in situ hybridization signals, dark blue; arrow). C: No positive in situ hybridization signals in endothelial cells of SARS lungs when using an irrelevant probe (in situ hybridization with methyl green counterstaining). D: Masson trichrome stain (blue stain) highlights marked fibrosis in the lung of a SARS patient with a clinical course of 33 days before death. E: Double labeling combining IHC for vimentin and in situ hybridization shows SARS-CoV in some vimentin-positive spindle-shaped cells (arrow) (consecutive section to D). F: Double labeling with CK and in situ hybridization demonstrates SARS-CoV in a few CK-negative spindle-shaped cells ( in situ hybridization signals, dark blue; arrow) (consecutive section to E). Scale bars: $25 \mu \mathrm{m}$ (A-C); $20 \mu \mathrm{m}$ (D-F).

\section{Fibroblasts}

The lungs of cases 003, 005, and 006 showed zones of marked fibrosis (Figure 3D). Within these zones, there were spindle-shaped cells in which strongly positive signals were detected by in situ hybridization. Double labeling combining in situ hybridization and $\mathrm{IHC}$ demonstrated that these cells were vimentin-positive (Figure 3E) and CK-negative (Figure 3F). The finding that such cells were located within an area of fibrosis, as well as the spindle-shaped histomorphology, the absence of $\mathrm{CK}$ reactivity, and the vimentin-positive staining, all support the presumption that these cells are fibroblasts. Masson trichrome stain in consecutive sections also demonstrated staining of these cells appropriate for fibroblasts (Figure 3D).

The specificities of the in situ hybridization, $\mathrm{IHC}$, and double labeling were established by the negative results in the negative controls (Figures $1 \mathrm{H}$ and $3 \mathrm{C}$ ).

\section{Statistical Analysis}

The scatter plot comparing the infection rates of $\mathrm{CD}^{+}$cells and $\mathrm{CK}^{+}$cells appeared to show a negative correlation, excluding case 008 (Figure 4). The Spearman's correlation coefficient and $P$ value (including all seven cases) were -0.107 and 0.819 , respectively. The Spearman's correlation test (excluding case 008) showed a negative correlation (Spearman's correlation coefficient $=-0.771$ ), although lacking statistical significance $(P=0.072)$. The scatter plots comparing the other variables did not show any obvious linear trend (scatter plots not shown).

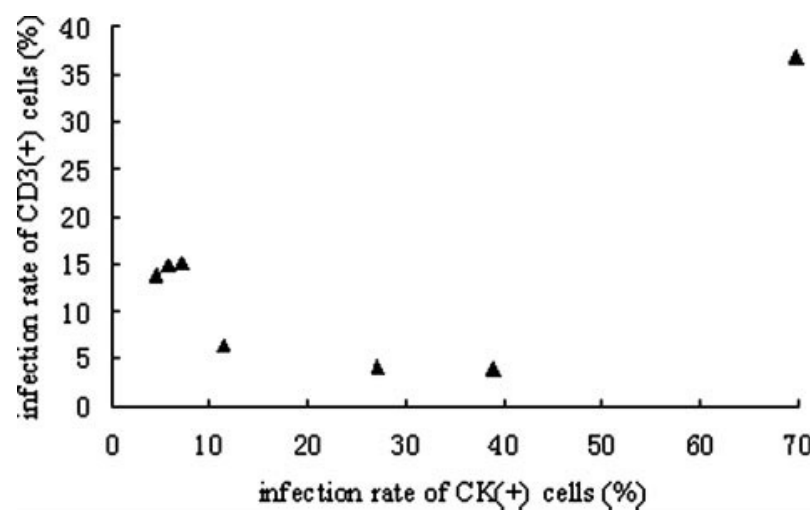

Figure 4. Scatter plot comparing the infection rates of cytokeratin-positive cells and CD3-positive cells. A negative linear relationship can be seen, excluding case 008. 


\section{Discussion}

Although the last SARS outbreak is now more than 2 years past, the pathogenesis of this disease is still incompletely understood. In particular, the detailed pathology and cell types infected, their distribution, and quantity in the major target organ of SARS have not been thoroughly investigated. In the present study, in situ hybridization, $\mathrm{IHC}$, and $\mathrm{HC}$ were used to profile the cellular distribution of SARS-CoV in pulmonary tissues.

Consistent with previous studies, ${ }^{4,9-13}$ SARS-CoV was found to be readily identifiable in pneumocytes, bronchial epithelium, macrophages, and T lymphocytes. It is noteworthy that in case 008 , who had a relatively short clinical course, the pathological changes in the lung were still in a relatively early phase, and a high percentage of pneumocytes and T lymphocytes were infected.

The pathological significance of infection of immune cells has recently been discussed by Gu and colleagues, ${ }^{12}$ who have argued that infected immune cells, such as lymphocytes and macrophages/monocytes, may carry SARS-CoV to various organs as manifested by widespread dissemination. Furthermore, direct infection and subsequent damage to immune cells may result in a transient compromised immune system that could aggravate the pulmonary injury. ${ }^{12}$

SARS-CoV infection of macrophages may play an additional role in the pathogenesis of SARS lungs. In vitro experiments have demonstrated that infection of macrophages induced expression of certain chemokines. ${ }^{16}$ In addition, little or no interferon response could be elicited by SARS$\mathrm{CoV}$ infection of macrophages in the same experiments. Both increased levels of chemokines and deficiency of the interferon- $\beta$ response may result in exacerbation of the local inflammatory reaction in SARS lungs. ${ }^{16}$ We found SARSCoV in both large and small CD68-positive cells. The latter cells most likely represent small nonactivated macrophages/monocytes. This would suggest that the virus cannot only be ingested by activated macrophages but may also be capable of directly infecting small nonactivated macrophages and monocytes.

In previous reports on SARS, extensive pathological lesions of hemorrhage, edema, vasculitis, and thrombus have all been described, appearing to be directly related to vascular endothelial injury.2,6,8 These pathological changes may have contributed, among other factors, to cause the reduced oxygenation found in SARS patients. In this study, we found that SARS-CoV is capable of infecting vascular endothelial cells. This may indicate that direct infection of such cells partly accounts for the observed injury of vascular endothelium. However, the paucity of infected endothelial cells seems insufficient to explain the severe vascular injury. Previous studies have reported high levels of various cytokines and chemokines in the serum of SARS patients. ${ }^{17,18}$ We therefore assume that in addition to direct viral infection, both hyperinduction of proinflammatory mediators and hypoxia may play an important role in the injury of vascular endothelium in SARS patients.

Pathologically, there are two types of pulmonary fibrosis, interstitial and intra-alveolar, ${ }^{19}$ both of which have been observed in SARS. 3,5,7 Fibroblast activation and overexpression of collagen are important aspects of the pathogenesis of fibrosis. Injured epithelial cells, infiltrating inflammatory cells, and elevated cytokines all have an important role in the process of activation of fibroblasts and collagen synthesis. ${ }^{19}$ Our findings of direct SARSCoV infection of fibroblasts suggest that SARS-CoV and its proteins may interact with host cells, thus further contributing to the activation of fibroblasts and excessive production of collagen.

The distribution of virus in the cells of the lungs of SARS patients unveiled in this study raises a question as to the mechanism of infection of diverse cell types. Angiotensinconverting enzyme 2 (ACE2) has been identified as the functional receptor for SARS-CoV. ${ }^{20,21}$ This receptor is expressed abundantly in tracheal epithelium, pneumocytes, and vascular endothelium but not in lymphocytes, macrophages, or fibroblasts. ${ }^{22}$ It is thus possible that SARS-CoV infects epithelial cells of the trachea, pneumocytes, and vascular endothelial cells (all expressing ACE2), through interaction of the spike protein and ACE2, and then replicates in these cells to cause intercellular transmission. However, the mechanism by which SARS-CoV infects cells that do not express ACE2 receptors is unclear. In this study, both lymphocytes and macrophages harbored viral genomic sequences and had high infection rates, despite the absence of ACE2 expression. A possible explanation is that ACE2-negative cells, such as macrophages, are infected on contact with the basolateral aspect of infected epithelial cells by direct cell-cell contact or engulfment. In measles, this kind of indirect infection has been described to account for the infection of tissue-resident macrophages and dendritic cells. ${ }^{23}$

In addition, other receptors may play a role in direct infection of ACE2-negative cells. Both lymph node-specific ICAM3-grabbing nonintegrin (L-SIGN), and dendritic-cell-specific ICAM3-grabbing nonintegrin (DC-SIGN) have been reported to function as receptors for SARSCoV. ${ }^{24-26}$ DC-SIGN expression has been detected in certain types of dendritic cells and alveolar macrophages, ${ }^{27}$ which may explain the presence of SARS-CoV genomic sequences in lung tissue macrophages as observed in this study. However, in vitro experiments have demonstrated that cells expressing DC-SIGN or L-SIGN without ACE2 are not or are only partially susceptible to SARS-CoV infection. ${ }^{24-26}$ This suggests that these receptors are much less efficient than ACE2 receptors and merely enhance infection of susceptible cells. ${ }^{24-26}$ All these findings suggest that other receptors and/or cofactors may be involved in the interaction between the virus and the target cells.

ACE2 has been reported to be expressed efficiently in endothelial cells. ${ }^{22}$ Nevertheless, in our cases only a few endothelial cells showed positive viral expression. Studies in a new human cell culture model have indicated that the presence of ACE2 alone is insufficient for maintaining viral infection. ${ }^{28}$ Huang and colleagues $^{29}$ have suggested that cathepsin L may facilitate SARS-CoV infection mediated by the spike protein. Mature endothelial cells express relatively low levels of cathepsin $L,{ }^{30}$ which 
may explain the low infection rate of these cells despite the high expression of ACE2. ${ }^{29}$

\section{Acknowledgments}

We thank Drs. Zifen Gao, Zigang Xei, and Min Lu of the Department of Pathology of Peking University Health Science Center for performing the relevant autopsies and providing the tissue samples; and the Lifu Foundation of Taiwan for their support.

\section{References}

1. Tsang KW, Ho PL, Ooi GC, Yee WK, Wang T, Chan-Yeung M, Lam WK, Seto WH, Yam LY, Cheung TM, Wong PC, Lam B, Ip MS, Chan $\mathrm{J}$, Yuen KY, Lai KN: A cluster of cases of severe acute respiratory syndrome in Hong Kong. N Engl J Med 2003, 348:1977-1985

2. Ding Y, Wang H, Shen H, Li Z, Geng J, Han H, Cai J, Li X, Kang W, Weng D, Lu Y, Wu D, He L, Yao K: The clinical pathology of severe acute respiratory syndrome (SARS): a report from China. J Pathol 2003, 200:282-289

3. Franks TJ, Chong PY, Chui P, Galvin JR, Lourens RM, Reid AH, Selbs E, McEvoy CP, Hayden CD, Fukuoka J, Taubenberger JK, Travis WD: Lung pathology of severe acute respiratory syndrome (SARS): a study of 8 autopsy cases from Singapore. Hum Pathol 2003, 34:734-748

4. To KF, Tong JH, Chan PK, Au FW, Chim SS, Chan KC, Cheung JL, Liu EY, Tse GM, Lo AW, Lo YM, Ng HK: Tissue and cellular tropism of the coronavirus associated with severe acute respiratory syndrome: an in-situ hybridization study of fatal cases. J Pathol 2004, 202:157-163

5. Tse GM, To KF, Chan PK, Lo AW, Ng KC, Wu A, Lee N, Wong HC, Mak SM, Chan KF, Hui DS, Sung JJ, Ng HK: Pulmonary pathological features in coronavirus associated severe acute respiratory syndrome (SARS). J Clin Pathol 2004, 57:260-265

6. Nicholls JM, Poon LL, Lee KC, Ng WF, Lai ST, Leung CY, Chu CM, Hui PK, Mak KL, Lim W, Yan KW, Chan KH, Tsang NC, Guan Y, Yuen KY, Peiris JS: Lung pathology of fatal severe acute respiratory syndrome. Lancet 2003, 61:1773-1778

7. Cheung OY, Chan JW, Ng CK, Koo CK: The spectrum of pathological changes in severe acute respiratory syndrome (SARS). Histopathology 2004, 45:119-124

8. Lang Z, Zhang L, Zhang S, Meng X, Li J, Song C, Sun L, Zhou Y: Pathological study on severe acute respiratory syndrome. Chin Med J (Engl) 2003, 116:976-980

9. Chow KC, Hsiao CH, Lin TY, Chen CL, Chiou SH: Detection of severe acute respiratory syndrome-associated coronavirus in pneumocytes of the lung. Am J Clin Pathol 2004, 121:574-580

10. Shieh WJ, Hsiao CH, Paddock CD, Guarner J, Goldsmith CS, Tatti K, Packard M, Mueller L, Wu MZ, Rollin P, Su IJ, Zaki SR: Immunohistochemical, in situ hybridization, and ultrastructural localization of SARS-associated coronavirus in lung of a fatal case of severe acute respiratory syndrome in Taiwan. Hum Pathol 2005, 36:303-309

11. Ding $Y$, He L, Zhang Q, Huang Z, Che X, Hou J, Wang H, Shen H, Qiu L, Li Z, Geng J, Cai J, Han H, Li X, Kang W, Weng D, Liang P, Jiang S: Organ distribution of severe acute respiratory syndrome (SARS) associated coronavirus (SARS-CoV) in SARS patients: implications for pathogenesis and virus transmission pathways. J Pathol 2004, 203:622-630

12. Gu J, Gong E, Zhang B, Zheng J, Gao Z, Zhong Y, Zou W, Zhan J, Wang S, Xie Z, Zhuang H, Wu B, Zhong H, Shao H, Fang W, Gao D, Pei F, Li X, He Z, Xu D, Shi X, Anderson VM, Leong AS: Multiple organ infection and the pathogenesis of SARS. J Exp Med 2005, 202:415-424

13. Nicholls JM, Butany J, Poon LL, Chan KH, Beh SL, Poutanen S, Peiris JS, Wong M: Time course and cellular localization of SARS-CoV nucleoprotein and RNA in lungs from fatal cases of SARS. PLoS Med 2006, 3:e27
14. Zhang QL, Ding YQ, Hou JL, He L, Huang ZX, Wang HJ, Cai JJ, Zhang JH, Zhang WL, Geng H, Li X, Kang W, Yang L, Shen H, Li ZG, Han HX, Lu YD: Detection of SARS coronavirus in human tissues by in situ hybridization. Appl Immunohist Mol Morphol 2003, 11:285

15. Lin Y, Shen X, Yang RF, Li YX, Ji YY, He YY, Shi MD, Lu W, Shi TL, Wang J, Wang HX, Jiang HL, Shen JH, Xie YH, Wang Y, Pei G, Shen $\mathrm{BF}$, Wu JR, Sun B: Identification of an epitope of SARS-coronavirus nucleocapsid protein. Cell Res 2003, 13:141-145

16. Cheung CY, Poon LL, Ng IH, Luk W, Sia SF, Wu MH, Chan KH, Yuen KY, Gordon S, Guan Y, Peiris JS: Cytokine responses in severe acute respiratory syndrome coronavirus-infected macrophages in vitro: possible relevance to pathogenesis. J Virol 2005, 79:7819-7826

17. Wong CK, Lam CW, Wu AK, Ip WK, Lee NL, Chan IH, Lit LC, Hui DS, Chan $\mathrm{MH}$, Chung SS, Sung JJ: Plasma inflammatory cytokines and chemokines in severe acute respiratory syndrome. Clin Exp Immunol 2004, 136:95-103

18. Zhang Y, Li J, Zhan Y, Wu L, Yu X, Zhang W, Ye L, Xu S, Sun R, Wang $\mathrm{Y}$, Lou J: Analysis of serum cytokines in patients with severe acute respiratory syndrome. Infect Immun 2004, 72:4410-4415

19. Kuwano K, Hagimoto N, Hara N: Molecular mechanisms of pulmonary fibrosis and current treatment. Curr Mol Med 2001, 1:551-573

20. Li W, Moore MJ, Vasilieva N, Sui J, Wong SK, Berne MA, Somasundaran $\mathrm{M}$, Sullivan JL, Luzuriaga K, Greenough TC, Choe H, Farzan M: Angiotensin-converting enzyme 2 is a functional receptor for the SARS coronavirus. Nature 2003, 426:450-454

21. Wang P, Chen J, Zheng A, Nie Y, Shi X, Wang W, Wang G, Luo M, Liu $H$, Tan L, Song X, Wang Z, Yin X, Qu X, Wang X, Qing T, Ding M, Deng $\mathrm{H}$ : Expression cloning of functional receptor used by SARS coronavirus. Biochem Biophys Res Commun 2004, 315:439-444

22. Hamming I, Timens W, Bulthuis MLC, Lely AT, Navis GJ, Goor HV Tissue distribution of ACE2 protein, the functional receptor for SARS coronavirus-A first step in understanding SARS pathogenesis. J Pathol 2004, 203:631-637

23. Naim HY, Ehler E, Billeter MA: Measles virus matrix protein specifies apical virus release and glycoprotein sorting in epithelial cells. EMBO J 2000, 19:3576-3585

24. Jeffers SA, Tusell SM, Gillim-Ross L, Hemmila EM, Achenbach JE, Babcock GJ, Thomas Jr WD, Thackray LB, Young MD, Mason RJ, Ambrosino DM, Wentworth DE, Demartini JC, Holmes KV: CD209L (L-SIGN) is a receptor for severe acute respiratory syndrome coronavirus. Proc Natl Acad Sci USA 2004, 101:15748-15753

25. Marzi A, Gramberg T, Simmons G, Moller P, Rennekamp AJ, Krumbiegel M, Geier M, Eisemann J, Turza N, Saunier B, Steinkasserer A, Becker S, Bates P, Hofmann H, Pohlmann S: DC-SIGN and DCSIGNR interact with the glycoprotein of Marburg virus and the $S$ protein of severe acute respiratory syndrome coronavirus. J Virol 2004, 78:12090-12095

26. Yang ZY, Huang Y, Ganesh L, Leung K, Kong WP, Schwartz O, Subbarao K, Nabel GJ: pH-dependent entry of severe acute respiratory syndrome coronavirus is mediated by the spike glycoprotein and enhanced by dendritic cell transfer through DC-SIGN. J Virol 2004, 78:5642-5650

27. Soilleux EJ, Morris LS, Leslie G, Chehimi J, Luo Q, Levroney E, Trowsdale J, Montaner LJ, Doms RW, Weissman D, Coleman N, Lee $\mathrm{B}$ : Constitutive and induced expression of DC-SIGN on dendritic cell and macrophage subpopulations in situ and in vitro. J Leukoc Biol 2002, 71:445-457

28. Chan PK, To KF, Lo AW, Cheung JL, Chu I, Au FW, Tong JH, Tam JS Sung JJ, Ng HK: Persistent infection of SARS coronavirus in colonic cells in vitro. J Med Virol 2004, 74:1-7

29. Huang IC, Bosch BJ, Li F, Li W, Lee KH, Ghiran S, Vasilieva N, Dermody TS, Harrison SC, Dormitzer PR, Farzan M, Rottier PJ, Choe $\mathrm{H}$ : SARS coronavirus, but not human coronavirus NL63, utilizes cathepsin L to infect ACE2-expressing cells. J Biol Chem 2006, 281:3198-3203

30. Urbich C, Heeschen C, Aicher A, Sasaki K, Bruhl T, Farhadi MR, Vajkoczy P, Hofmann WK, Peters C, Pennacchio LA, Abolmaali ND, Chavakis E, Reinheckel T, Zeiher AM, Dimmeler S: Cathepsin L is required for endothelial progenitor cell-induced neovascularization. Nat Med 2005, 11:206-213 